\begin{tabular}{|l|l|l|}
\hline \multicolumn{2}{|c|}{ PublisherInfo } \\
\hline \hline PublisherName & $:$ & BioMed Central \\
\hline \hline PublisherLocation & $:$ & London \\
\hline \hline PublisherImprintName & $:$ & BioMed Central \\
\hline \hline
\end{tabular}

\title{
A novel mode of action of IL-4?
}

\begin{tabular}{||l|l|l||}
\hline \multicolumn{2}{|c||}{ ArticleInfo } \\
\hline \hline ArticleID & $:$ & 37 \\
\hline \hline ArticleDOI & $:$ & $10.1186 /$ ar-1999-66752 \\
\hline \hline ArticleCitationID & $:$ & 66752 \\
\hline \hline ArticleSequenceNumber & $:$ & 33 \\
\hline \hline ArticleCategory & $:$ & Paper Report \\
\hline \hline ArticleFirstPage & $:$ & 1 \\
\hline \hline ArticleLastPage & $:$ & 3 \\
\hline \hline & & RegistrationDate : 1999-11-25 \\
ArticleHistory & $:$ & OnlineDate $: 1999-11-25$ \\
\hline \hline ArticleCopyright & $:$ & Current Science Ltd1999 \\
\hline \hline ArticleGrants & $:$ & \\
\hline \hline ArticleContext & $:$ & 130752211 \\
\hline \hline
\end{tabular}


Keywords

Interleukin-4, lipoxygenase, PPAR, transcription

\section{Context}

Peroxisome proliferator-activated receptor $\hat{\mathrm{I}}^{3}\left(\operatorname{PPAR} \hat{\mathrm{I}}^{3}\right)$ is a member of the nuclear hormone receptor family of transcription factors. It is able to both activate and repress transcription, and is reported to negatively regulate macrophage function. Ligands for PPARI $\hat{I}^{3}$ include anti-diabetic thiazolidinedione drugs, and various metabolites of arachidonic and linoleic acids (AA and LA). Whilst the addition of exogenous PPAR $\hat{I}^{3}$-activating ligands can block the expression of proinflammatory gene products such as inducible nitric oxide synthase (iNOS), interleukin-1 $\mathrm{I} \pm(\mathrm{IL}-1 \hat{\mathrm{I}} \pm$ ) and IL-6 in macrophages, the source and identity of endogenous PPAR $\hat{I}^{3}$ ligands are not known. A 12/15-lipoxygenase (LOX) is induced by IL-4 treatment of macrophages, and is able to metabolise AA or LA to form PPARI ${ }^{3}$ ligands. However, the role of this enzyme in the regulation of macrophage gene expression is not yet known. To investigate the production of PPAR $\hat{I}^{3}$-activating ligands in cells of the myeloid lineage, and the role of these ligands in the regulation of gene expression.

\section{Significant findings}

In RAW264.7 cells expressing PPARI $\hat{I}^{3}$, a PPAR $\hat{I}^{3}$-dependent promoter was activated by exogenous ligands (AA and LA metabolites or thiazolidinediones). Coexpression of lipoxygenase allowed AA to activate the promoter in a PPAR $\hat{I}^{3}$-dependent manner. By transfection of PA317 cells which either express or lack lipoxygenase activity, it was confirmed that this enzyme acts as a source of PPARI $\mathrm{I}^{3}$ activating ligands. Negative regulation of the iNOS promoter in RAW264.7 cells was dependent upon PPAR $\hat{I}^{3}$ and ligand, which could be provided by the action of lipoxygenase upon LA.

In mouse macrophages IL-4 induced the expression of PPAR $\hat{I}^{3} 1$. The expression of CD36 (a putative scavenger receptor for oxidized low density lipoproteins) was induced by IL-4, and this was blocked by a lipoxygenase inhibitor or a PPAR $\hat{I}^{3}$ antagonist. A mouse lipoxygenase knockout was deficient in IL-4-induced CD36 expression.

\section{Comments}


The only entirely novel finding presented here is the induction of PPAR $\hat{I}^{3}$ by IL-4; however, this is an excellent piece of research which pulls together several strands in the regulation of macrophage function, and suggests a novel and interesting mode of action for the anti-inflammatory cytokine IL-4. An interesting property of the synthetic PPARI ligands, which is addressed here only in transfected $R A W 264.7$ cells, is the ability to negatively regulate macrophage gene expression. It would be interesting to determine whether a PPAR $\hat{I}^{3}$ mechanism is involved in inhibitory effects of IL-4 upon macrophage genes (such as $i N O S, I L-1 \hat{I} \pm$ or IL-6) in vivo. PPARs are expressed in activated macrophages (for example in atherosclerotic plaques), provoking an interest in PPAR ligands as potential anti-inflammatory agents. The side-effects of such drugs will be an important consideration. Finally, the mechanism of negative regulation of gene expression by PPAR is not addressed in this paper, however, there is another report, by Delerive et al , (J Biol Chem 1999, 274: 32048-32054 [Report]), which does address this.

\section{Methods}

Mouse peritoneal macrophages and human peripheral blood monocytes were obtained by standard methods. Ribonuclease protection assays and western blots were used to examine endogenous gene expression at mRNA and protein levels. Studies of transcriptional regulation were by transient transfection, with various reporter constructs, of RAW264.7 (mouse macrophage) or PA317 (mouse fibroblast) cells.

\section{References}

1. Huang JT, Welch JS, Ricote M, Binder CJ, Willson TM, Kelly C, Witztum JL: Interleukin-4-dependent production of PPAR- $\hat{\mathrm{I}}^{3}$ ligands in macrophages by 12/15-lipoxygenase. Nature. 1999, 400: 378-382.

This PDF file was created after publication. 